\title{
Barley allele-specific amplicons useful for identifying wheat-barley recombinant chromosomes
}

\author{
Koji Murai ${ }^{1, *}$, Shin Taketa ${ }^{2}$, A. K. M. Rafiqul Islam ${ }^{3}$, and Ken W. Shepherd ${ }^{3}$ \\ ${ }^{1}$ Department of Bioscience, Fukui Prefectural University, Matsuoka-cho, Fukui 910-1195, Japan \\ ${ }^{2}$ Department of Life Sciences, Faculty of Agriculture, Kagawa University, Ikenobe, \\ Kagawa 761-0795, Japan \\ ${ }^{3}$ Department of Plant Science, Waite Campus, University of Adelaide, \\ Glen Osmond, SA 5064, Australia
}

(Received 21 May, 1999, accepted 26 May 2000)

\begin{abstract}
Barley (Hordeum vulgare L.) is potentially a new source of genes for wheat (Triticum aestivum L.) improvement. Wheat-barley chromosome recombinant lines provide a means for introgressing barley genes to wheat genome by chromosome engineering, and since these are expected to occur only rarely in special cytogenetic stocks, an efficient selection skill is necessary to identify them. To convert RFLP markers to barley allele-specific PCR markers useful for effective production of wheat-barley recombinant lines, 91 primer sets derived from RFLP clones which were previously mapped to the barley chromosomes were examined for PCR amplification using 'Chinese Spring' wheat, 'Betzes' barley and the wheat-barley chromosome addition lines. The polymorphisms were detected by an agarose gel electrophoresis of the PCR products without digestion with restriction enzymes. Out of 81 primer sets producing polymorphisms between the wheat and barley genomes, 26 amplified barley chromosome-specific DNAs which were confirmed to be located on the same chromosome as the RFLP markers by using the wheat-barley chromosome addition lines. These amplified DNAs represent barley allele-specific amplicons, which distinguish barley alleles from their wheat homoeologous counterparts. The present investigation revealed a higher probability for obtaining allele-specific amplicons from genomic DNA-derived RFLP markers than from cDNA-derived ones. The barley allele-specific amplicons developed in this study, namely, four for chromosome $2 \mathrm{H}$, two for $3 \mathrm{H}$, seven for $4 \mathrm{H}$, eight for $5 \mathrm{H}$, one for $6 \mathrm{H}$ and four for $7 \mathrm{H}$, are suitable for identifying 'Chinese Spring' wheat- 'Betzes' barley recombinant chromosomes. However, one out of eight barley allele-specific amplicons on chromosome $5 \mathrm{H}$ did not detect a unique barley band in a 'New Golden' barley chromosome $5 \mathrm{H}$ addition line of 'Shinchunaga' wheat, indicating there may be a need to reconstruct allele-specific amplicons with different barley cultivars.
\end{abstract}

\section{INTRODUCTION}

Introgression of genetic materials, particularly disease resistance genes, from related species such as Aegilops, Agropyron and Secale has been widely used for the improvement of bread wheat (Triticum aestivum L.) (reviewed in Islam and Shepherd, 1991; Mujeeb-Kazi, 1993). Barley (Hordeum vulgare L.) is a potential new source of genes for wheat improvement, e.g., genes conferring resistance to barley yellow dwarf virus (McGuire and Qualset, 1990), leaf and yellow rust (Islam and Shepherd, 1990), cereal cyst nematode (Islam and Shepherd, 1992),

Edited by Takashi Endo

* Corresponding author. E-mail: murai@fpu.ac.jp
Russian wheat aphid (Nieto-Lopez and Blake, 1994), and Karnal bunt (Chauhan and Singh, 1994). Recently, Murai et al. (1997a) examined heading characters of wheat-barley chromosome addition lines produced by Islam et al. (1981) and Koba et al. (1997), and found that barley chromosome $5 \mathrm{H}$ has genetic effects on accelerating narrow-sense earliness, decreasing vernalization requirement and/or increasing photoperiodic sensitivity. To introduce the barley genes for early heading on chromosome $5 \mathrm{H}$ into wheat, we are planning to produce wheat-barley 5H chromosome recombinant lines (Murai et al. 1997b).

To transfer alien gene into wheat, it is preferable if the wheat and alien chromosomes can be induced to pair and recombine at meiosis. However, a major problem for producing wheat-barley recombinant lines is the low pairing 
frequency between wheat and barley chromosomes, resulting in a low frequency of recombinants. Islam and Shepherd $(1988,1992)$ reported that barley chromosomes paired with their wheat homoeologues with frequencies ranging from 0.3 to $2.6 \%$. Because of this low frequency of pairing, it is necessary to have an effective selection system to detect the rare wheat-barley recombinants. Islam and Shepherd (1992) used five isozyme markers for selecting wheat-barley recombinants involving chromosomes $3 \mathrm{H}$ or $6 \mathrm{H}$. However, isozyme markers are not widely applicable for this purpose because the number of suitably located markers is limited. Murai (1995) developed 22 barley chromosome-specific RAPD (random amplified polymorphic DNA) markers, but their locations within chromosomes are not known.

Several RFLP (restriction fragment length polymorphism) maps have been developed in barley (Graner et al., 1991; Heun et al., 1991; Kleinhofs et al., 1993; Langridge et al., 1995; Qi et al., 1996), and these RFLP markers have been used as informative molecular markers in genome analysis. However, RFLP analysis is too time consuming and expensive to apply to the large-scale screening for wheat-barley recombinant lines. Conversion of RFLP markers to STS (sequence tagged site)-PCR (polymerase chain reaction) markers offers several experimental advantages, i.e., they can be applied to relatively small amounts of DNA and can be applied rapidly and cheaply. When RFLP markers are converted to STS-PCR markers, it is crucial to confirm that they occur at the same chromosome location. Erpelding et al. (1996) found that the RFLP and equivalent STS-PCR markers were located on the same chromosomes in barley in 28 cases out of 50. More recently, Mano et al. (1999) identified the chromosome locations of 38 STS-PCR markers and observed that the locations were identical with those of the RFLP markers except in three cases. These results emphasize that re-localization of the STS-PCR markers is necessary after their conversion from an RFLP marker. Furthermore, STS-PCR markers often require a restriction enzyme digestion following amplification to produce a polymorphism (Tragoonrung et al., 1992). For the efficient screening of rare wheat-barley recombinants, it would be more suitable to use direct amplification of barley alleles (allele-specific amplicons) which can be distinguished from their wheat counterparts without restriction enzyme digestion. Blake et al. (1996) reported 135 barley allele-specific amplicons amplified by 115 primer sets developed from sequences of previously mapped RFLP clones. In their procedure, PCR products were electrophoresed in a $6 \%$ polyacrylamide gel for $2.5 \mathrm{~h}$. However, the barley allelespecific amplicons would be more convenient for practical use if they could be detected more rapidly by an agarose gel electrophoresis. Here we describe a simplified detection of barley allele-specific amplicons using electrophoresis of the PCR products in a $1.5 \%$ agarose gel for $0.5 \mathrm{~h}$ at
$100 \mathrm{~V}$.

The present experiments were designed (1) to evaluate 91 PCR primer sets derived from RFLP markers to determine which of these produced polymorphisms between 'Chinese Spring' wheat and 'Betzes' barley with the simplified detection system, (2) to localize the barley-specific amplified DNAs by using the wheat-barley chromosome addition lines, and (3) to optimize annealing condition for each primer set. Out of the 91 primer sets, 40 had been examined earlier by Blake et al. (1996) and found to produce barley allele-specific amplicons. These primer sets were re-examined for producing barley allele-specific amplicons with the simplified detection system. The remaining 51 primer sets were newly tested to search for additional barley allele-specific amplicons.

\section{MATERIALS AND METHODS}

Plant materials. Polymorphism of PCR products between wheat and barley was detected using 'Chinese Spring' wheat and 'Betzes' barley as reference samples. A set of wheat-barley disomic addition lines possessing each of 'Betzes' chromosomes $2 \mathrm{H}$ to $7 \mathrm{H}$ in the background of 'Chinese Spring' (Islam et al., 1981) were used to localize the PCR products to the barley chromosomes. Addition line $1 \mathrm{H}$ was not available because of problems of sterility when it is added to wheat (Islam et al., 1981). Furthermore, a 'New Golden' barley chromosome 5H addition line of 'Shinchunaga' wheat (Koba et al. 1997) was used for amplification of barley allele-specific amplicons on chromosome $5 \mathrm{H}$. The nomenclature for the barley chromosomes is based on their homeologous relationships with the wheat chromosomes, i.e., barley chromosome $1=7 \mathrm{H}, 2=2 \mathrm{H}, 3=3 \mathrm{H}, 4=4 \mathrm{H}, 5=1 \mathrm{H}, 6=6 \mathrm{H}$ and $7=5 \mathrm{H}$ (Linde-Laursen et al., 1997).

Primer evaluation. A total of 91 primer sets developed from the sequences of previously mapped barley RFLP clones were evaluated (Table 1). The primer sets were developed from several sources: (1) barley genomic DNA clones (ABG and BG; Kleinhofs et al., 1993; Heun et al., 1991); (2) barley cDNA clones (ABC and BCD; Kleinhofs et al., 1993; Heun et al., 1991); (3) wheat genomic DNA clones (WG; Heun et al., 1991); (4) oat cDNA clones (CDO; Heun et al., 1991), and others. Following Larson et al. (1996), the PCR primers/markers were distinguished from RFLP clones/markers by using the small-case letter " $a$ " in front of the marker locus name. Multiple primer sets were developed from several RFLP clones; e.g., both aABG473.1 and aABG473.11 were from RFLP clone ABG473. The sequence data of the primer sets are available on GrainGenes (WWW server: http://wheat.pw. usda.gov/). The data sources are Drs. Tom Blake, Andris Kleinhofs, Mark E. Sorrells, Bikram S. Gill, Gottfried Kuenzel, and Andreas Graner. The aBmy1 primer set 
Table 1. List of primer sets used in this study, together with the chromosome location of RFLP markers from which the PCR primers were derived

\begin{tabular}{|c|c|c|c|c|c|c|c|c|c|}
\hline Primer name ${ }^{a}$ & RFLP-1 ${ }^{b}$ & RFLP-2 ${ }^{c}$ & $\operatorname{STS}^{\mathrm{d}}$ & Amplicon $^{\mathrm{e}}$ & Primer name ${ }^{a}$ & RFLP-1 $^{\mathrm{b}}$ & RFLP-2 ${ }^{\mathrm{c}}$ & $\operatorname{STS}^{\mathrm{d}}$ & Amplicon \\
\hline aABG318 & $2 \mathrm{H}$ & $2 \mathrm{HS}$ & nd & IV & aCDO749 & $5 \mathrm{H}$ & $5 \mathrm{HS}$ & nd & IV \\
\hline aABG2.1 & $2 \mathrm{H}$ & $2 \mathrm{HS}$ & nd & V & aWG530 & $5 \mathrm{H}$ & $5 \mathrm{HL}$ & nd & IV \\
\hline aABG358.1 & $2 \mathrm{H}$ & $2 \mathrm{HS}$ & nd & $\mathrm{V}$ & aBG123 & $2 \mathrm{H}, 5 \mathrm{H}$ & $2 \mathrm{HL}$ & $5 \mathrm{H}$ & $\mathrm{I}(5 \mathrm{H})$ \\
\hline aABG459 & $2 \mathrm{H}$ & $2 \mathrm{HS}$ & $3 \mathrm{H}$ & IV & aABC302.3 & $5 \mathrm{H}$ & $5 \mathrm{HL}$ & $5 \mathrm{H}, 7 \mathrm{H}$ & III \\
\hline $\mathrm{aCDO} 370$ & $2 \mathrm{H}$ & $2 \mathrm{HS}$ & nd & IV & aWG564.1 & $5 \mathrm{H}$ & $5 \mathrm{HL}$ & nd & IV \\
\hline aABG602 & $2 \mathrm{H}$ & nd & $2 \mathrm{H}, 4 \mathrm{H}, 6 \mathrm{H}$ & III & $\mathrm{aABC} 168$ & $5 \mathrm{H}$ & $5 \mathrm{HL}$ & $4 \mathrm{H}$ & IV \\
\hline aABG716 & $2 \mathrm{H}$ & nd & $2 \mathrm{H}$ & III & aABG473.1 & $5 \mathrm{H}$ & $5 \mathrm{HL}$ & $5 \mathrm{H}, 6 \mathrm{H}$ & I \\
\hline aCDO770 & $2 \mathrm{H}$ & $2 \mathrm{HS}$ & nd & IV & aABG473.11 & $5 \mathrm{H}$ & $5 \mathrm{HL}$ & $5 \mathrm{H}$ & III \\
\hline $\mathrm{aABC} 468$ & $2 \mathrm{H}$ & $2 \mathrm{HS}$ & $4 \mathrm{H}$ & IV & $\mathrm{aABC} 717$ & $5 \mathrm{H}$ & $5 \mathrm{HL}$ & $5 \mathrm{H}$ & $\mathrm{I}$ \\
\hline aABG356 & $2 \mathrm{H}$ & $2 \mathrm{HS}$ & $2 \mathrm{H}$ & III & aWG1026.1 & $4 \mathrm{H}, 5 \mathrm{H}$ & $5 \mathrm{HL}$ & nd & $\operatorname{III}(5 \mathrm{H})$ \\
\hline aWG996 & $2 \mathrm{H}$ & $2 \mathrm{HL}$ & $7 \mathrm{H}$ & IV & aABG712 & $5 \mathrm{H}$ & $5 \mathrm{HL}$ & $5 \mathrm{H}$ & III \\
\hline aABG14.1 & $2 \mathrm{H}$ & $2 \mathrm{HL}$ & nd & II & $\mathrm{aABC} 155$ & $5 \mathrm{H}$ & $5 \mathrm{HL}$ & $5 \mathrm{H}$ & I \\
\hline aCDO588.1 & $2 \mathrm{H}$ & $2 \mathrm{HL}$ & nd & IV & aCDO213 & $5 \mathrm{H}$ & $5 \mathrm{HL}$ & $6 \mathrm{H}, 7 \mathrm{H}$ & IV \\
\hline $\mathrm{aABC} 153$ & $2 \mathrm{H}$ & $2 \mathrm{HL}$ & nd & I & $\mathrm{aABC} 622$ & $5 \mathrm{H}$ & nd & nd & IV \\
\hline aCDO395 & $3 \mathrm{H}$ & $3 \mathrm{HS}$ & nd & $\mathrm{V}$ & aABG707 & $5 \mathrm{H}$ & $5 \mathrm{HL}$ & nd & V \\
\hline $\mathrm{aABG} 471$ & $3 \mathrm{H}$ & $3 \mathrm{HS}$ & $6 \mathrm{H}$ & IV & aABG463 & $5 \mathrm{H}$ & $5 \mathrm{HL}$ & nd & IV \\
\hline aWG178 & $3 \mathrm{H}$ & $3 \mathrm{HL}$ & ond & & aABG314 & $5 \mathrm{H}(2)$ & nd & nd & II \\
\hline aABG396.1 & $3 \mathrm{H}$ & $\begin{array}{l}3 \mathrm{HL} \\
3 \mathrm{HS}\end{array}$ & na & IV & aABC309 & $5 \mathrm{H}$ & $5 \mathrm{HL}$ & nd & IV \\
\hline aABC 323 & $3 \mathrm{H}$ & nd & $2 \mathrm{H}$ & $\begin{array}{l}\text { III } \\
\text { IV }\end{array}$ & aCDO506 & $5 \mathrm{H}$ & $5 \mathrm{HL}$ & nd & IV \\
\hline aBCD828 & $3 \mathrm{H}$ & $3 \mathrm{HS}$ & nd & IV & aABG378 & $6 \mathrm{H}$ & $6 \mathrm{HS}$ & $6 \mathrm{H}$ & III \\
\hline aABG377 & $3 \mathrm{H}$ & $3 \mathrm{HL}$ & $3 \mathrm{H}$ & III & aABG62 & nd & $6 \mathrm{HS}$ & nd & IV \\
\hline aWG940 & $3 \mathrm{H}$ & $3 \mathrm{HL}$ & $4 \mathrm{H}$ & IV & aABG474 & $6 \mathrm{H}$ & $6 \mathrm{HS}$ & nd & II \\
\hline aABG4 & $3 \mathrm{H}$ & $3 \mathrm{HL}$ & $2 \mathrm{H}, 4 \mathrm{H}$ & IV & aABG20.1 & $6 \mathrm{H}$ & $6 \mathrm{HS}$ & nd & IV \\
\hline aWG110.1 & $3 \mathrm{H}$ & $3 \mathrm{HL}$ & nd & $\mathrm{V}$ & aBCD269 & $6 \mathrm{H}$ & $6 \mathrm{HL}$ & $3 \mathrm{H}$ & IV \\
\hline aABC166 & $3 \mathrm{H}$ & $3 \mathrm{HL}$ & nd & IV & $\mathrm{aABC} 170$ & $6 \mathrm{H}(2)$ & nd & $2 \mathrm{H}$ & IV \\
\hline aWG622 & $4 \mathrm{H}$ & $4 \mathrm{HS}$ & nd & $\mathrm{V}$ & aABA301 & $7 \mathrm{H}$ & $7 \mathrm{HS}$ & nd & $\mathrm{V}$ \\
\hline aABG3.1 & $4 \mathrm{H}$ & $4 \mathrm{HS}$ & nd & IV & aABG704 & $7 \mathrm{H}$ & $7 \mathrm{HS}$ & nd & $\mathrm{V}$ \\
\hline $\mathrm{aABG} 484$ & $4 \mathrm{H}$ & $4 \mathrm{HS}$ & $4 \mathrm{H}$ & III & aABG77 & $7 \mathrm{H}$ & nd & nd & II \\
\hline aWG232.1 & $4 \mathrm{H}$ & $4 \mathrm{HS}$ & $6 \mathrm{H}$ & IV & aABG75 & $7 \mathrm{H}$ & 7HS & $3 \mathrm{H}$ & IV \\
\hline aWG464 & $4 \mathrm{H}$ & $4 \mathrm{HL}$ & $4 \mathrm{H}$ & III & aBCD129 & $7 \mathrm{H}$ & 7HS & nd & IV \\
\hline aCDO541 & $4 \mathrm{H}$ & $4 \mathrm{HL}$ & nd & $\mathrm{V}$ & $\mathrm{aCDO545.1}$ & $7 \mathrm{H}$ & $7 \mathrm{HS}$ & nd & IV \\
\hline aWG181 & $4 \mathrm{H}$ & $4 \mathrm{HL}$ & nd & IV & $\mathrm{aCDO} 475$ & $7 \mathrm{H}$ & $7 \mathrm{HS}$ & $4 \mathrm{H}$ & IV \\
\hline $\mathrm{aABG} 472$ & $4 \mathrm{H}$ & $4 \mathrm{HL}$ & $4 \mathrm{H}$ & I & aABG380 & $7 \mathrm{H}$ & $7 \mathrm{HS}$ & nd & III \\
\hline aABG394 & $4 \mathrm{H}$ & $4 \mathrm{HL}$ & $4 \mathrm{H}$ & III & $\mathrm{aABC} 158$ & $7 \mathrm{H}$ & $7 \mathrm{HS}$ & nd & IV \\
\hline aABG618 & $4 \mathrm{H}$ & nd & $4 \mathrm{H}$ & III & aCDO36 & $7 \mathrm{H}$ & nd & nd & IV \\
\hline aWG114 & $4 \mathrm{H}$ & $4 \mathrm{HL}$ & nd & II & $\mathrm{aABC} 465$ & $7 \mathrm{H}$ & $7 \mathrm{HS}$ & $7 \mathrm{H}$ & III \\
\hline aABG54 & $4 \mathrm{H}$ & $4 \mathrm{HL}$ & $4 \mathrm{H}$ & III & $\mathrm{aABC} 255$ & $7 \mathrm{H}$ & $7 \mathrm{HS}$ & $7 \mathrm{H}$ & III \\
\hline aABG397.1 & $4 \mathrm{H}$ & $4 \mathrm{HL}$ & $5 \mathrm{H}$ & IV & $\mathrm{aABC} 308$ & $7 \mathrm{H}$ & 7HS & nd & IV \\
\hline aABG397.2 & $4 \mathrm{H}$ & $4 \mathrm{HL}$ & nd & IV & $\mathrm{aCDO} 464$ & $7 \mathrm{H}$ & $7 \mathrm{HL}$ & nd & IV \\
\hline aABG366 & $4 \mathrm{H}$ & $4 \mathrm{HL}$ & nd & IV & aWG719 & $7 \mathrm{H}$ & $7 \mathrm{HS}$ & nd & IV \\
\hline $\mathrm{aCDO} 63$ & $4 \mathrm{H}$ & $4 \mathrm{HL}$ & nd & IV & $\mathrm{aABC} 254$ & $7 \mathrm{H}$ & $7 \mathrm{HS}$ & nd & IV \\
\hline aABG601 & $4 \mathrm{H}$ & nd & nd & IV & $\mathrm{aABC} 455$ & $7 \mathrm{H}$ & $7 \mathrm{HS}$ & $4 \mathrm{H}$ & IV \\
\hline aBCD402.1 & $4 \mathrm{H}(2)$ & $4 \mathrm{HL}$ & $6 \mathrm{H}$ & IV & $\mathrm{aABC} 310$ & $5 \mathrm{H}, 7 \mathrm{H}$ & $7 \mathrm{HL}$ & $6 \mathrm{H}$ & $\mathrm{I}(7 \mathrm{H})$ \\
\hline $\mathrm{aBCD} 402.11$ & $4 \mathrm{H}(2)$ & $4 \mathrm{HL}$ & nd & IV & $\mathrm{aABC} 305$ & $7 \mathrm{H}$ & $7 \mathrm{HL}$ & $6 \mathrm{H}$ & IV \\
\hline $\mathrm{aBCD} 402.12$ & $4 \mathrm{H}(2)$ & $4 \mathrm{HL}$ & nd & IV & $\mathrm{aABG} 461$ & $7 \mathrm{H}$ & $7 \mathrm{HL}$ & nd & $\mathrm{V}$ \\
\hline aBmy1 & $4 \mathrm{H}$ & $4 \mathrm{HL}$ & nd & I & & & & & \\
\hline
\end{tabular}

${ }^{a}$ Primers are listed in the order of the RFLP marker position in each chromosome, i.e., from distal in short arm to distal in long arm, according to the RFLP map of Qi et al. (1996).

The position of aABG62 was determined from the RFLP map of Langridge et al. (1995).

${ }^{\mathrm{b}}$ Chromosome location of the RFLP markers following Qi et al. (1996). (2) indicates two loci of the RFLP clone were observed in the same chromosome. nd means not determined.

${ }^{\mathrm{c}}$ Chromosome location of the RFLP markers following Langridge et al. (1995). nd means not determined.

${ }^{\mathrm{d}}$ Chromosome location of the STS-PCR markers following Blake et al. (1996). nd means not determined.

${ }^{\mathrm{e}}$ Classification of primer sets revealed by this study (refer to Table 2). Chromosome location of amplicon is indicated by parentheses when the parent RFLP marker is located on two different chromosomes.

was derived from the RFLP marker Bmy1 corresponding to barley $\beta$-amylase gene (Kreis et al., 1987), which was located on chromosome 4H RFLP map (Langridge et al.,
1995; Qi et al., 1996).

Plant DNA was extracted by a modified CTAB method described previously (Abo-elwafa et al., 1995) and used as 
a template for the PCR assay. Each $20 \mu \mathrm{l}$ amplification reaction consisted of $10 \mathrm{mM}$ Tris- $\mathrm{HCl}(\mathrm{pH} 9.0), 50 \mathrm{mM} \mathrm{KCl}$, $0.1 \%$ Triton X-100, $1.5 \mathrm{mM} \mathrm{MgCl}_{2}, 160 \mu \mathrm{M}$ each of dNTPs, $200 \mathrm{nM}$ primer, $0.5 \mathrm{U}$ of Taq polymerase (Gibco BRL; Toyobo), and about 50ng of template DNA. Amplification was performed under the following conditions: at $94^{\circ} \mathrm{C}$ for $3 \mathrm{~min}$; followed by 30 cycles at 45,50 or $55^{\circ} \mathrm{C}$ for $1 \mathrm{~min}$, at $72^{\circ} \mathrm{C}$ for $2 \mathrm{~min}$, and at $94^{\circ} \mathrm{C}$ for $1 \mathrm{~min}$; followed by at $72^{\circ} \mathrm{C}$ for $3 \mathrm{~min}$. Amplification products were separated on $1.5 \%$ agarose gel for $0.5 \mathrm{~h}$ at $100 \mathrm{~V}$ and visualized with ethidium bromide.

Southern hybridization analysis. Five barley allelespecific amplicons on chromosome $5 \mathrm{H}$, aABC302.3, aABG473.1, aWG1026.1, aABG712 and aABC155, were subjected to Southern analysis to determine the relationship of the PCR products to the corresponding RFLP clones used to design the primer sets. PCR products were transferred to a nylon membrane (Hybond $\mathrm{N}^{+}$, Amersham), hybridized with the RFLP clones, and detected using the ECL direct nucleic acid labeling and detection system (Amersham).

\section{RESULTS AND DISCUSSION}

Classification of PCR primer sets. Initially all of the 91 primer sets developed from RFLP clones were evaluated by PCR assay at $45^{\circ} \mathrm{C}$ as the annealing temperature to determine whether they produced polymorphisms between 'Chinese Spring' wheat and 'Betzes' barley without digestion with restriction enzymes (Table 1). A total of 81 primer sets were found to produce barley-specific PCR products. The chromosome locations of the barley-specific amplified DNAs were determined by analyzing the wheat-barley chromosome addition lines. The PCR primer sets were classified into five classes (Table 2). Class I and II primer sets amplified DNAs from barley but not from wheat. Class III and IV produced PCR products (including minor amplified DNAs) from both wheat and barley, but the products were different in size. The barley-specific PCR products amplified with Class I and III primers and the RFLP markers from which the PCR primers were developed were found to be located on the same chromosomes. With Class II and IV, RFLP markers had a different chromosome location from the barley-specific PCR products. Class V primer sets gave PCR products with the same size in both wheat and barley, and further treatments such as restriction digestion would have been necessary to produce polymorphisms.

In barley, Erpelding et al. (1996) reported that the chromosome locations of PCR products matched those of the RFLP markers in 28 cases out of 50 (56\%). In our data, however, PCR products were localized on the same chromosomes as the RFLP markers in only 26 cases (with Class I and III primer sets) out of 91 (29\%). Several factors are thought to have contributed to the disagreement between the chromosome locations of RFLP markers determined by linkage analysis and those of the PCR markers determined by analysis of wheat-barley addition lines. One contributor was due to the lack of polymorphism between wheat and barley, which prevented localization of the PCR products. To overcome this problem, restriction digestion of the PCR products would be expected to increase the frequency of polymorphisms and allow mapping of the PCR markers, as used by Erpelding et al. (1996). Another possible contributor is that the PCR primers amplified sequences from multiple loci on different chromosomes. Alternatively, some PCR prim-

Table 2. Classification of PCR primer sets based on the amplification of wheat and barley DNAs, and number of primers belonging to each class

\begin{tabular}{|c|c|c|c|c|c|c|c|c|c|}
\hline \multirow[b]{2}{*}{ Clas: } & \multicolumn{4}{|c|}{ PCR amplification } & \multicolumn{5}{|c|}{ "Source of RFLP clone ${ }^{a}$} \\
\hline & $\mathrm{CS}^{\mathrm{b}}$ & $\mathrm{Be}^{\mathrm{b}}$ & $\mathrm{CS}-\mathrm{Be}^{\mathrm{c}}$ & $\begin{array}{l}\text { Speci- } \\
\text { ficity }^{d}\end{array}$ & $\begin{array}{l}\text { Barley } \\
\text { genomic } \\
(\mathrm{ABG}, \mathrm{BG})\end{array}$ & $\begin{array}{l}\text { Barley } \\
\text { cDNA } \\
(\mathrm{ABC}, \mathrm{BCD})\end{array}$ & $\begin{array}{l}\text { Wheat } \\
\text { genomic } \\
\text { (WG) }\end{array}$ & $\begin{array}{l}\text { Oat } \\
\text { cDNA } \\
\text { (CDO) }\end{array}$ & Others $^{\mathrm{e}}$ \\
\hline I & - & + & & + & 3 & 4 & 0 & 0 & 1 \\
\hline II & - & + & & - & 4 & 0 & 1 & 0 & 0 \\
\hline III & + & + & Poly. & + & 13 & 3 & 2 & 0 & 0 \\
\hline IV & + & + & Poly. & - & 13 & 18 & 8 & 11 & 0 \\
\hline V & + & + & Iden. & & 5 & 0 & 2 & 2 & 1 \\
\hline Total & & & & & 38 & 25 & 13 & 13 & 2 \\
\hline $\mathrm{I}+\mathrm{II}$ & $I^{f}(\%$ & & & & 42.1 & 28.0 & 15.4 & 0 & - \\
\hline
\end{tabular}

${ }^{a}$ RFLP clone source from which the primer sets were designed

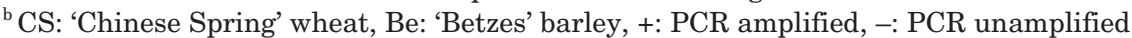

${ }^{c}$ Poly.: Polymorphic between CS and Be in major and/or minor PCR products, Iden.: Identical in both major and minor PCR products

d +: Barley chromosome-specific, -: Unspecific

e aBmy1 (Class I) and aABA301 (Class V)

${ }^{\mathrm{f}}$ Percentage of PCR primer sets producing barley allele-specific amplified DNAs 
Table 3. Barley allele-specific amplicons developed

\begin{tabular}{|c|c|c|c|c|c|c|}
\hline \multirow{2}{*}{$\begin{array}{l}\text { Primer }^{\mathrm{a}} \\
\text { Name }\end{array}$} & \multirow{2}{*}{$\begin{array}{c}\text { Sequence } \\
\left(5^{\prime}-3^{\prime}\right)\end{array}$} & \multirow{2}{*}{$\begin{array}{l}\text { Optimal } \\
\text { annealing } \\
\text { Temp. }\left({ }^{\circ} \mathrm{C}\right)\end{array}$} & \multicolumn{2}{|c|}{ PCR products ${ }^{b}$} & \multirow{2}{*}{$\begin{array}{l}\text { Size of } \\
\text { amplicon } \\
(\mathrm{bp})^{\mathrm{c}}\end{array}$} & \multirow{2}{*}{$\begin{array}{l}\text { Chromo- } \\
\text { some }\end{array}$} \\
\hline & & & $\mathrm{CS}$ & $\mathrm{Be}$ & & \\
\hline \multirow[t]{2}{*}{ aABG602 } & C T T C CTTCTATCGCCT TCTC & 55 & ++ & + & 1080 & $2 \mathrm{H}$ \\
\hline & GCAAAATCCCTCCATACATC & & & & & \\
\hline \multirow[t]{2}{*}{ aABG716 } & C T C CACACCATACT TGAATC & 55 & + & + & 1140 & $2 \mathrm{H}$ \\
\hline & A T G G C A T T A GA A G T C GA T C T & & & & & \\
\hline \multirow[t]{2}{*}{ aABG356 } & T C A A C T GAGGTAGA A T A T A & 55 & $-*$ & ++ & $410(510)^{\mathrm{d}}$ & $2 \mathrm{H}$ \\
\hline & C CAACAATAAAGAATCAAAT & & & & & \\
\hline \multirow[t]{2}{*}{$\underline{\mathrm{aABC} 153}$} & GCCTCTGCCGCTGGA A C T A C & 55 & - & + & 270 & $2 \mathrm{H}$ \\
\hline & A A A C ACCTCCTGGCTCTCAG & & & & & \\
\hline \multirow[t]{2}{*}{ aABG396.1 } & A GGAAACCTATGTAATCATC & 55 & + & + & 360 & $3 \mathrm{H}$ \\
\hline & GGG T C A C A A A GA C GGAGGA G & & & & & \\
\hline \multirow{2}{*}{ aABG377 } & GTGTTACAGCCACCTATT TC & 55 & -* & + & 460 & $3 \mathrm{H}$ \\
\hline & GCTGCTATGAGGAGAGAAC C & & & & & \\
\hline \multirow[t]{2}{*}{ aABG484 } & TAGT TAGAGAGGGA A A C A & 55 & $-*$ & + & 1030 & $4 \mathrm{H}$ \\
\hline & TAAATCACCAACATTGAAAC & & & & & \\
\hline \multirow[t]{2}{*}{ aWG464 } & A GTC C A A A T GATGTCACAGG & 55 & + & +++ & 1420 & $4 \mathrm{H}$ \\
\hline & A GGACTGTGAAGATGCTACT & & & & & \\
\hline \multirow[t]{2}{*}{ aABG472 } & GGGATT T GGAAAAAGT T T A T & 50 & - & + & 870 & $4 \mathrm{H}$ \\
\hline & GGCGAAGATGTCCTTAGATA & & & & & \\
\hline \multirow[t]{2}{*}{ aABG394 } & CGATGTAATAAAAATTAGGT & 50 & ++ & + & 280 & $4 \mathrm{H}$ \\
\hline & GGGTGTTGCTCATGCTCTTT & & & & & \\
\hline \multirow[t]{2}{*}{ aABG618 } & C T G T GGTCATCAAT C C A G T G & 55 & $-*$ & + & 560 & $4 \mathrm{H}$ \\
\hline & GT TCATCTCAACGGGTCAGT & & & & & \\
\hline \multirow[t]{2}{*}{ aABG54 } & GT GCT T GGCGGTCGAC C A G T & 55 & +++ & +++ & 270 & $4 \mathrm{H}$ \\
\hline & GATGTC CA ACGGTGGCT T GA & & & & & \\
\hline \multirow[t]{2}{*}{$\underline{\mathrm{aBmy} 1}$} & GATGAAGCAAACAAGGTC & 50 & - & + & 1200 & $4 \mathrm{H}$ \\
\hline & C A C A TAACATAAAGGGTAGTAAA & & & & & \\
\hline aBG123 & T C C A A GAAGAGTCAAGTAAA & 50 & - & + & 1420 & $5 \mathrm{H}$ \\
\hline & $C A A G C A G T A G G A A T A A G A A C$ & & & & & \\
\hline aАBC302.3 & A T A A GGA A C A GGA A C A G A G T & 55 & ++ & + & 870 & $5 \mathrm{H}$ \\
\hline & A T A A A GGAGAAGATTGAGTC & & & & & \\
\hline aABG473.1 & T G T C GCT T T A C T G T A T T T A T & 55 & - & + & 370 & $5 \mathrm{H}$ \\
\hline & A C T T T GT TCTCCATTATGAG & & & & & \\
\hline aABG473.11 & GGGCAATGTCGCTTTACTGT & 55 & -* & + & 280 & $5 \mathrm{H}$ \\
\hline & T T C C TGGCTACAAATACACC & & & & & \\
\hline aABC717 & CAATACGGCAACAAATAACA & 55 & - & + & 730 & $5 \mathrm{H}$ \\
\hline & C C C CACCAAAATTACCAGTC & & & & & \\
\hline aWG1026.1 & A T G G G A T C A C C T G GAGGATG & 55 & + & + & 950 & $5 \mathrm{H}$ \\
\hline & TGCTAAACAAAGACTTGCTG & & & & & \\
\hline aABG712 & A A A T A T GGT T GG T C A A A G T T & 55 & +++ & +++ & 460 & $5 \mathrm{H}$ \\
\hline & GCT TCTGGTCTGTGTTCT T G & & & & & \\
\hline aABC155 & TCTGTGTGTTATTCCTCTTA & 55 & - & + & 410 & $5 \mathrm{H}$ \\
\hline & A C GAAAAATCAATACTGGTC & & & & & \\
\hline aABG378 & T TAGTCATAGAATCCCTGTT & 55 & + & + & 230 & $6 \mathrm{H}$ \\
\hline & A A A A T TCGCCTGTGCTGTGT & & & & & \\
\hline$\underline{\mathrm{aABG} 380}$ & CACGAACAGAAGGAGACTAA & 50 & -* $^{*}$ & ++ & $400(340)^{\mathrm{d}}$ & $7 \mathrm{H}$ \\
\hline & A A A C C C TACATCATCTTTTT & & & & & \\
\hline aABC465 & GCTACTGGGACAAAATCTCC & 55 & $-*$ & + & 540 & $7 \mathrm{H}$ \\
\hline & $C A C G A C A G A C G G A C C A A A T G$ & & & & & \\
\hline aABC255 & GA T C A T C G T G GATGGAGT G T & 55 & -* & + & 650 & $7 \mathrm{H}$ \\
\hline & CGAATTCCGAGACATCAAAT & & & & & \\
\hline$\underline{\mathrm{aABC} 310}$ & T C C T GATGGTC C T C T T A T G C & 55 & - & + & 1520 & $7 \mathrm{H}$ \\
\hline & A C A T A GTTCTCTTCC CAGTA & & & & & \\
\hline
\end{tabular}


ers might have amplified nonhomologous sequences. Finally, structural changes to the added barley chromosome, such as deletion or insertion, might have occurred during introgression of the barley chromosome to wheat background, resulting in failure of PCR products to be amplified.

Class I and III primer sets produced barley-specific PCR products allowing barley alleles to be distinguished from their wheat homoeologous counterparts without restriction digestion. These PCR products can be regarded as barley allele-specific amplicons, and they were found in approximately $42 \%$ of the primers derived from genomic DNAs and approximately $28 \%$ of those from cDNAs (Table 2 ). This difference in frequency is probably due to the cDNA-derived RFLP clones often being sequences of multiple loci whereas genomic DNA-derived RFLP clones have unique sequences. The aBmy1 primer directs specific amplification of the barley $\beta$-amylase gene locus, indicating that sequences of cloned genes are a good source for developing allele-specific amplicons.

Development of barley allele-specific amplicons. For Class I and III primer sets, the PCR assay was conducted at annealing temperatures of 50 and $55^{\circ} \mathrm{C}$ to determine the optimal annealing temperature for barley allele-specific amplicons. Table 3 summarizes the PCR patterns obtained with 'Chinese Spring' and 'Betzes' with optimal annealing temperature and the sizes of barley allele-specific amplicons. In some cases, unspecific (minor) PCR products disappeared when the optimal annealing temperature was used (Fig. 1). Altogether, we developed 26 barley-allele specific amplicons, namely, four for chromosome $2 \mathrm{H}$, two for $3 \mathrm{H}$, seven for $4 \mathrm{H}$, eight for $5 \mathrm{H}$, one for $6 \mathrm{H}$ and four for $7 \mathrm{H}$. As shown in Fig. 2, there were two types of barley allele-specific amplicons. In the first type, the PCR product was obtained from barley DNA but not from wheat DNA (for example, aABG484 amplicon). In the second type, the amplified DNAs differed in their sizes between wheat and barley (for example, aWG464). Amplicons of the latter type are likely to be more informative than the former because they can be used as co-dominant markers.

Blake et al. (1996) detected 135 barley allele-specific amplicons amplified by 115 primer sets. We re-examined 40 of these primers and confirmed that barley allele-specific amplicons could be produced using our simplified detection system. Blake et al. (1996) counted barley-spe-

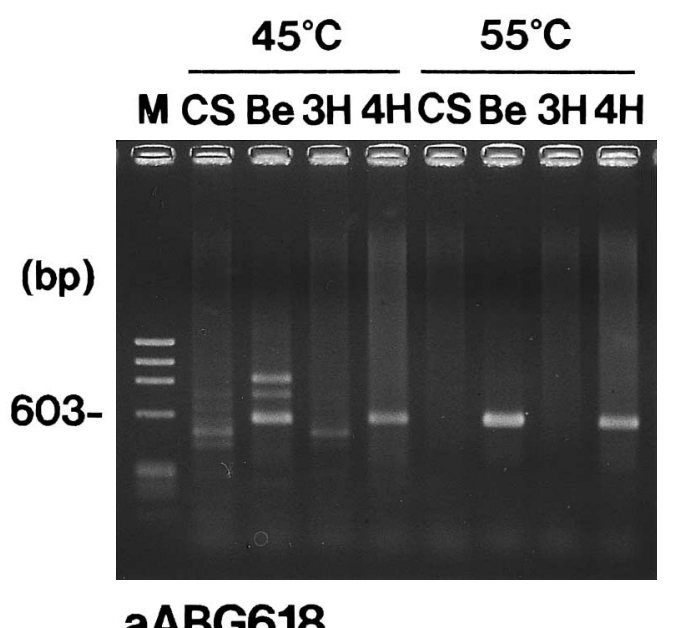

Fig. 1. Amplification with the primer set aABG618 under different annealing temperature $\left(45\right.$ or $\left.55^{\circ} \mathrm{C}\right)$, for 'Chinese Spring' wheat (CS), 'Betzes' barley (Be), and wheat-barley $3 \mathrm{H}$ and $4 \mathrm{H}$ chromosome addition lines ( $3 \mathrm{H}$ and $4 \mathrm{H}$, respectively). HaeIIIdigested $\phi x 174$ DNA is used as molecular weight marker (M).

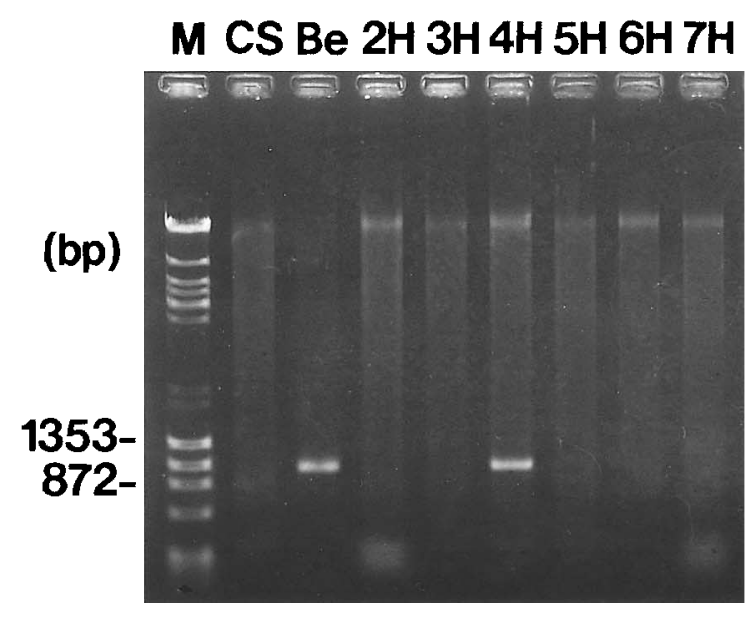

aABG484
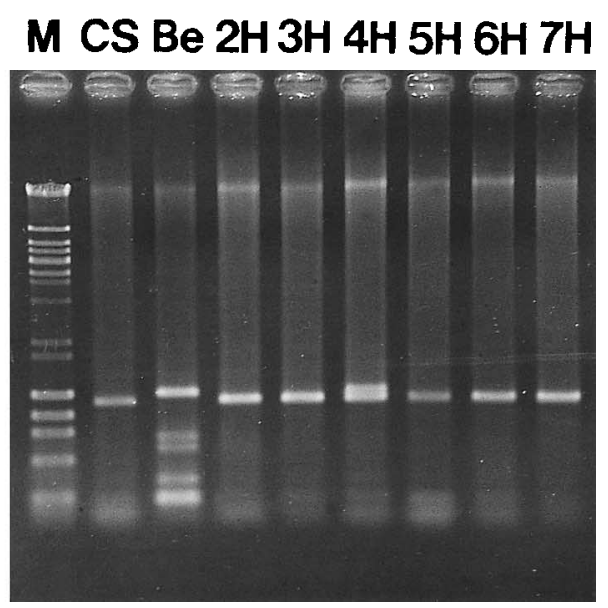

aWG464

Fig. 2. Amplification with the primer set aABG484 (left) and aWG464 (right) for the wheat-barley addition lines (2H-7H), along with 'Chinese Spring' wheat (CS) and 'Betzes' barley (Be). Mixture of HindIII-digested $\lambda$ DNA and HaeIII-digested $\phi x 174$ DNA is used as molecular weight marker (M). 


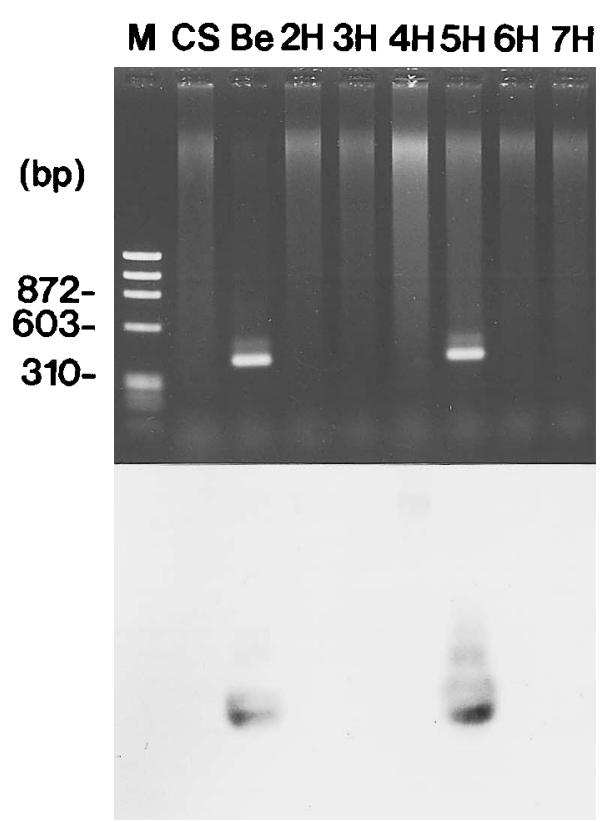

aABC155
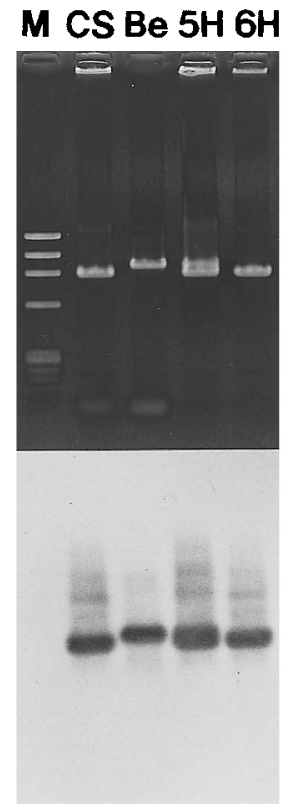

aWG1026.1
M CS Be $5 \mathrm{H} 6 \mathrm{H}$

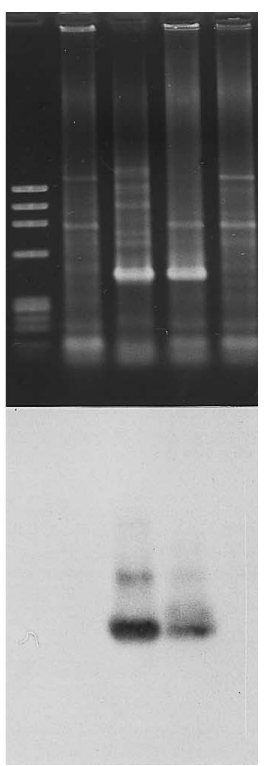

aABG712

Fig. 3. Amplification with the primer set aABC155 (left), aWG1026.1 (middle) and aABG712 (right) for the wheat-barley addition lines $(2 \mathrm{H}-7 \mathrm{H})$, along with 'Chinese Spring' wheat (CS) and 'Betzes' barley (Be), and Southern blots of the PCR products hybridized with corresponding RFLP clones. HaeIII-digested $\phi x 174$ DNA is used as molecular weight marker (M).

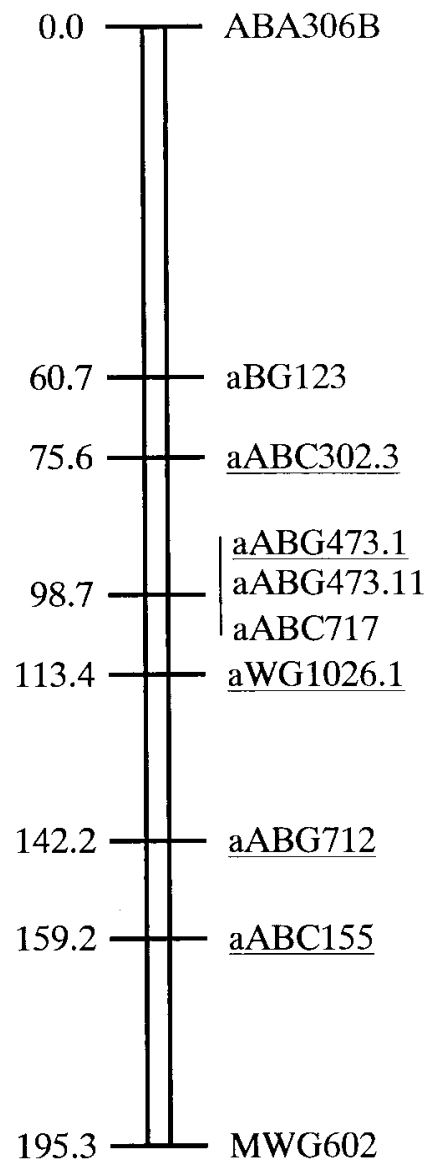

$(\mathrm{cM})$ cific PCR products that were located on a different chromosome to the RFLP markers among the barley allele-specific amplicons. In our study, however, only those barley-specific PCR products which had the same chromosome location as the parent RFLP markers were considered to be barley allele-specific amplicons. The present data were consistent with the results of Blake et al. (1996), except for the location of aABC310 (Table 1). This disagreement might have resulted from the different PCR conditions used in the two studies. Five of the 26 amplicons listed in Table 3, namely, aABC153 on chromosome $2 \mathrm{H}$, aBmy1 on $4 \mathrm{H}$, aWG1026.1 on $5 \mathrm{H}$, aABG380 and aABC310 on $7 \mathrm{H}$, were novel barley allele-specific amplicons.

PCR markers are expected to share the same locus as their parent RFLP makers with the consequence that an RFLP marker and its PCR derivative should lie on the same chromosome. However, Erpelding et al. (1996) found two exceptions in 14 cases where a PCR product located on the same chromosome as the RFLP marker failed to hybridize to its RFLP clone, indicating that nonhomologous sequences had been amplified and mapped to the chromosome. Furthermore, Larson et al. (1996) re-

Fig. 4. Linkage map of eight amplicons on chromosome $5 \mathrm{H}$ developed from RFLP markers. Map position of amplicons was cited from the RFLP map (Qi et al. 1996) with the assumption that an RFLP marker and the amplicon lie on the same locus. ABA306B and MWG602 are RFLP markers, and the chromosome is oriented with the short arm at the top. Underlined amplicons were confirmed to correspond with their parent RFLP clones by Southern hybridization analysis. 
ported that an STS-PCR marker did not coincide with the parent RFLP locus but it did map to the same chromosome. Therefore, linkage analysis of PCR markers or hybridization analysis between RFLP clones and their PCR products should be carried out to determine the location of the derived PCR markers. Five amplicons on chromosome 5H, namely, aABC302.3, aABG473.1, aWG1026.1, aABG712 and aABC155, were analyzed by Southern hybridizations to determine whether the PCR products were homologous to the corresponding RFLP clones used to design the primer sets. The results showed that all of the PCR primer sets tested amplified the sequences homologous to the RFLP clones (Fig. 3), demonstrating that the amplicons occupy the same loci as the parent RFLP markers. Based on the RFLP map of Qi et al. (1996), a linkage map of barley allele-specific amplicons on chromosome $5 \mathrm{H}$ is shown in Fig. 4.

To determine whether the barley allele-specific amplicons developed in this study are applicable for other wheat-barley genotypes, the primer sets producing barley allele-specific amplicons on chromosome $5 \mathrm{H}$ were examined for PCR amplification in a 'New Golden' barley chromosome $5 \mathrm{H}$ addition line of 'Shinchunaga' wheat. One out of eight barley allele-specific amplicons on chromosome $5 \mathrm{H}$, i.e., aABC155, did not amplify in the addition line having 'New Golden' chromosome 5H (Fig. 5). This suggests a need for reconstructing allele-specific amplicons in each barley cultivars used.

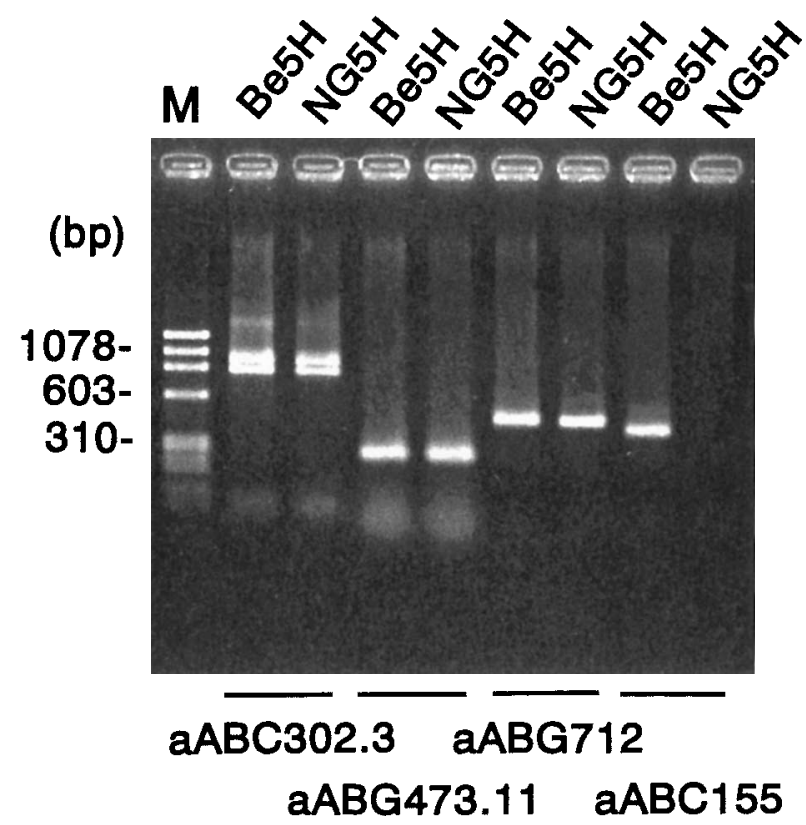

Fig. 5. Amplification with the primer sets yielding barley allelespecific amplicons on chromosome $5 \mathrm{H}$, i.e., aABC302.3, aABG473.11, aABG712, and aABC155 (left to right), for the 'Chinese Spring'wheat-'Betzes'barley $5 \mathrm{H}$ addition line $(\mathrm{Be} 5 \mathrm{H})$ and 'Shinchunaga' wheat-'New Golden' barley $5 \mathrm{H}$ addition line (NG5H). HaeIII-digested $\phi x 174$ DNA is used as molecular weight marker (M).
In conclusion, we developed 26 easily detectable barley allele-specific amplicons, five of which were novel barley allele-specific amplicons. Our main objective of developing barley allele-specific amplicons is to screen wheat-barley recombinant chromosomes for homoeologous group 5. Five barley allele-specific amplicons on the chromosome $5 \mathrm{H}$ are available for this purpose now. However, we did not get barley allele-specific amplicons located on short arm as well as distal position of long arm. To obtain new amplicons located on these regions, alternative methods such as development of amplicons from barley allele-specific RAPD markers (Murai 1995) should be introduced.

This work was initiated while the senior author was visiting the Department of Plant Science, University of Adelaide, and continued in the Research Institute of Agricultural Resources, Ishikawa Agricultural College. The authors thank Drs. T. Blake, Montana State University, and P. Langridge, University of Adelaide, for providing PCR primer sets. Thanks are also to Drs. M. Sorrells, Cornell University, A. Kleinhofs, Washington State University, and O. Anderson, USDA-ARS-WRRC, for RFLP clones, and to Dr. T. Koba, Chiba University for the 'New Golden' chromosome $5 \mathrm{H}$ addition wheat line.

\section{REFERENCES}

Abo-elwafa, A., Murai, K., and Shimada, T. (1995) Intra- and inter-specific variations in Lens revealed by RAPD markers. Theor. Appl. Genet. 90, 335-340.

Blake, T. K., Kadyrzhanova, D., Shepherd, K. W., Islam, A. K. M. R., Langridge, P. L., McDonald, C. L., Erpelding, J., Larson, S., Blake, N. K., and Talbert, L. E. (1996) STS-PCR markers appropriate for wheat-barley introgression. Theor. Appl. Genet. 93, 826-832.

Chauhan, R. S., and Singh, B. N. (1994) Karnal bunt resistance in wheat-barley addition lines. Plant Breed. 112, 252-255.

Erpelding, J. E., Blake, N. K., Blake, T. K., and Talbert, L. E. (1996) Transfer of sequence tagged site PCR markers between wheat and barley. Genome 39, 802-810.

Graner, A., Jahoor, A., Schondelmaier, J., Siedler, H., Pillen, K., Fischbeck, G., Wenzel, G., and Herrmann, R. G. (1991) Construction of an RFLP map of barley. Theor. Appl. Genet. 83, $250-256$.

Heun, M., Kennedy, A. E., Anderson, J. A., Lapitan, N. L. V., Sorrells, M. E., and Tanksley, S. D. (1991) Construction of a restriction fragment length polymorphism map for barley (Hordeum vulgare). Genome 34, 437-447.

Islam, A. K. M. R., and Shepherd, K. W. (1988) Induced pairing between wheat and barley chromosomes. Proc. $7^{\text {th }}$ Int. Wheat Genet. Symp., Cambridge, pp.309-314.

Islam, A. K. M. R., and Shepherd, K. W. (1990) Incorporation of barley chromosomes into wheat. In: Biotechnology in Agriculture and Forestry, Vol. 13, Wheat. (ed.: Y. P. S. Bajaj), pp.128-151. Springer-Verlag, Berlin.

Islam, A. K. M. R., and Shepherd, K. W. (1991) Alien genetic variation in wheat improvement. In: Chromosome Engineering in Plants: Genetics, Breeding, Evolution, Part A. (eds.: P. K. Gupta and T. Tsuchiya), pp.291-312. Elsevier Science Publishers B. V., Amsterdam.

Islam, A. K. M. R., and Shepherd, K. W. (1992) Production of wheat-barley recombinant chromosomes through induced homoeologous pairing. 1. Isolation of recombinants involving 
barley arms 3HL and 6HL. Theor. Appl. Genet. 83, 489494.

Islam, A. K. M. R., Shepherd, K. W., and Sparrow, D. H. B. (1981) Isolation and characterization of euplasmic wheat-barley chromosome addition lines. Heredity 46, 161-174.

Kleinhofs, A., Kilian, A., Saghai Maroof, M. A., Biyashev, R. M., Hayes, P., Chen, F. Q., Lapitan, N., Fenwick, A., Blake, T. K., Kanazin, V., Ananiev, E., Dahleen, L., Kudrna, D., Bollinger, J., Knapp, S. J., Liu, B., Sorrells, M., Heun, M., Franckowiak, J. D., Hoffman, D., Skadsen, R., and Steffenson, B. J. (1993) A molecular, isozyme and morphological map of the barley (Hordeum vulgare) genome. Theor. Appl. Genet. 86, 705-712.

Koba, T., Takumi, S., and Shimada, T. (1997) Isolation, identification and characterization of disomic and translocated barley chromosome addition lines of common wheat. Euphytica 96, 289-296.

Kreis, M., Williamson, M. S., Buxton, B., Pyrell, J., Hejgard, J., and Svendsen, I. (1987) Primary structure and differential expression of beta-amylase in normal and mutant barleys. Eurp. J. Biochem. 169, 517-525.

Langridge, P., Karakousis, A., Collins, N., Kretschmer, J., and Manning, S. (1995) A consensus linkage map of barley. Mol. Breed. 1, 389-395.

Larson, S. R., Kadyrzhanova, D., McDonald, C., Sorrells, M., and Blake, T. K. (1996) Evaluation of barley chromosome-3 yield QTLs in backcross $\mathrm{F}_{2}$ population using STS-PCR. Theor. Appl. Genet. 93, 618-625.

Linde-Laursen, I., Heslop-Harrison, J. S., Shepherd, K. W., and Taketa, S. (1997) The barley genome and its relationship with the wheat genes. A survey with an internationally agreed recommendation for barley chromosome nomenclature. Hereditas 126, 1-16.
Mano, Y., Sayed-Tabatabaei, B. E., Graner, A., Blake, T., Takaiwa, F., Oka, S., and Komatsuda, T. (1999) Map construction of sequence-tagged sites (STSs) in barley (Hordeum vulgare L.). Theor. Appl. Genet. 98, 937-946.

McGuire, P. E., and Qualset, C. O. (1990) Transfer of the Yd2 barley yellow dwarf virus resistance gene from barley to wheat. In: World Perspectives on Barley Yellow Dwarf Virus. (ed.: P. A. Burnett), pp.476-481. CIMMYT, Mexico.

Mujeeb-Kazi, A. (1993) Interspecific and intergeneric hybridization in the Triticeae for wheat improvement. In: Biodiversity in Wheat Improvement. (ed.: A. B. Damania), pp.95-102. John Wiley \& Sons, London.

Murai, K. (1995) Development of barley chromosome-specific RAPD markers for identification of barley chromosomes added to the wheat genome. Bull. Res. Inst. Agr. Resources, Ishikawa Agr. Coll. 4, 31-37.

Murai, K., Koba, T., and Shimada, T. (1997a) Effects of barley chromosome on heading characters in wheat-barley chromosome addition lines. Euphytica 96, 281-287.

Murai, K., Taketa, S., Islam, A. K. M. R., and Shepherd, K. W. (1997b) A simple procedure for the production of wheat-barley $5 \mathrm{H}$ chromosome recombinant lines utilizing 5B nullisomy and $5 \mathrm{H}$-specific molecular markers. Wheat Inf. Serv. 84, 5355.

Nieto-Lopez, R. M., and Blake, T. K. (1994) Russian wheat aphid resistance in barley: inheritance and linked molecular markers. Crop. Sci. 34, 655-659.

Qi, X., Stem, P., and Lindhout, P. (1996) Comparison and integration of four barley genetic maps. Genome 39, 379-394.

Tragoonrung, S., Kanazin, V., Hayes, P. M., and Blake, T. K. (1992) Sequence-tagged-site-facilitated PCR for barley genome mapping. Theor. Appl. Genet. 84, 1002-1008. 